\title{
Environmental filtering, not local adaptation of established plants determine the occurrence of seed- and bulbil-producing Poa alpina in a local flora
}

Jürg Stöcklin, Georg F.J. Armbruster

Institute of Botany, Department of Environmental Sciences, University of Basel, Schönbeinstrasse 6, CH-4056 Basel, Switzerland

Corresponding author. Tel.: +4161267 35 01; fax: +41612673500

E-mail address: juerg.stoecklin@unibas.ch (J. Stöcklin)

\begin{abstract}
Genetic variability among subspecies, ecotypes and populations is an important component of biodiversity, particularly when habitats are characterized by steep environmental gradients across short distances as in the landscape of the European Alps. In Poa alpina population differentiation is high due to polyploidy, facultative apomixis and the occurrence of seed- and bulbil-producing plants. We analysed microsatellite diversity of seed- and bulbil-producing populations from two nearby alpine grassland sites in the Swiss Alps and transplanted them reciprocally to test the hypothesis that established plants are locally adapted. The seed- and bulbil-producing populations differed molecularly strongly from each other despite their proximity. The seedproducing plants from the rich, calcareous grassland site performed well at both the home and the away site. Conversely, the bulbil-producing plants from the species-poor grassland had a comparatively low productivity at both sites, but performed better at the high-quality away site compared to its home site. Thus, local adaptation of established plants could not be confirmed by reciprocal transplantation. Results suggest that the distribution of seed- and bulbil-producing Poa alpina is a result of habitat quality, differences in plant performance, and the requirements for successful offspring recruitment. The prevailing occurrence of bulbil-producing plants at low productivity sites is probably due to different regeneration niches for seeds vs. bulbils, i.e. an advantage of bulbils at cold sites with poor soil and short growing seasons at this elevation.
\end{abstract}




\section{Zusammenfassung}

Genetische Variabilität zwischen Unterarten, Ökotypen und Populationen ist ein wichtiger Aspekt von Biodiversität, besonders, wenn die Habitate einer Art durch steile Umweltgradienten über kurze Distanzen getrennt sind, wie dies in der Landschaft der Europäischen Alpen der Fall ist. Bei Poa alpina ist die Differenzierung zwischen Populationen als Folge von Polyploidie, fakultativer Apomixis und durch die Bildung von Nachkommen aus Samen oder vegetativen Bulbillen besonders gross. Wir untersuchten mit Mikrosatelliten die molekulare Diversität von zwei Populationen nah benachbarter alpiner Rasen, von denen die eine mit Samen und die andere mit Bulbillen reproduziert. Die beiden Populationen wurden reziprok transplantiert, um auf lokale Anpassung etablierter Pflanzen zu testen. Trotz ihrer engen Nachbarschaft waren die Populationen molekular stark differenziert. Die Samen produzierenden Pflanzen des nährstoff- und artenreicheren Kalkrasens wuchsen sowohl am Heim- als auch am fremden Standort sehr gut. Umgekehrt zeigten die Bulbillen produzierenden Pflanzen des ärmeren Standorts ein vergleichsweise geringeres Wachstum an beiden Orten, wuchsen jedoch am fremden Standort höherer Qualität besser als an ihrem Heim-Standort. Lokale Anpassung etablierter Pflanzen konnte folglich durch reziproke Verpflanzung nicht nachgewiesen werden. Die Ergebnisse legen nahe, dass das unterschiedliche Vorkommen von Samen bzw. Bulbillen produzierenden Pflanzen eine Folge ist der verschiedenen Habitatsqualität, der unterschiedlichen Wüchsigkeit der Pflanzen aus den beiden Populationen sowie der spezifischen Anforderungen an die erfolgreiche Etablierung von Nachkommen. Das ausschliessliche Vorkommen von Bulbillen produzierenden Pflanzen in Habitaten geringerer Produktivität ist wohl in erster Linie eine Folge unterschiedlicher Etablierungsnischen von Samen und Bulbillen, insbesondere, dem Vorteil von Bulbillen an kühleren Standorten nährstoffarmer Böden mit einer sehr kurzen Wachstumsperiode.

Keywords: apomixis, genetic diversity, habitat quality, microsatellites, population performance, regeneration niche, reproductive mode 


\section{Introduction}

The rich flora of the European Alps reflects the strength of selective forces and evolutionary processes in the alpine landscape (Aeschimann et al., 2004). The actual distribution of alpine biodiversity mirrors evolutionary processes from the time when the Alps started to take shape, from migration and differential species survival during and after glaciations (Comes \& Kadereit, 1998; 2003), and was caused by the spatial and temporal heterogeneity of abiotic conditions which is particularly pronounced in the alpine landscape (Scherrer \& Körner, 2010). Alpine plants evolved striking adaptations to the conditions of their habitats at high elevation, to cold temperature, short vegetation periods, and the frequent occurrence of weather-related extreme events (Chapin \& Körner, 1995, Körner. 2003). In addition to species diversity, intraspecific variability is also large in alpine species, particularly when they are widespread. Landscape heterogeneity may lead to divergent natural selection, potentially resulting in adaptive genetic variation, and eventually leads to the formation of subspecies or ecotypes (Bennington \& Mc Graw, 1995; Manel et al., 2012). The pattern of intraspecific variability was the focus of the pioneering studies of Turesson (1922) and Clausen et al. (1948), and since then many studies have demonstrated intraspecific specialization to particular environmental conditions in alpine plants (McGraw et al., 1987; Galen et al., 1991; Byars et al., 2007; Byars \& Hoffmann; 2009; Stöcklin et al., 2009; Hautier et al., 2009; Frei et al., 2012; Scheepens et al., 2011; 2013).

Divergent natural selection is considered as the main evolutionary force causing populations to be locally adapted, i.e. to evolve traits providing them with a fitness advantage in their local habitat (Darwin, 1958; Williams, 1966). However, local adaptation may be constrained by gene flow, small population size, restricted genetic diversity or temporal variability (Bowmann et al., 2008), and diversification between species and populations may also result from non-adaptive processes such as mutations, gene flow, genetic drift, geographic isolation, hybridization, or polyploidy (Antonovics, 1976, Slatkin 1987, Young et al. 1996, Chun et al. 2009, Weiss-Schneeweiss et al. 2013). Furthermore, natural selection may have acted in the past, but the selective agents may not be present any more causing earlier fitness advantages to vanish (Harder \& Johnson, 2009).

Local adaptation is frequently believed to be the cause of differentiation but less often satisfactorily demonstrated. Local adaptation can be assumed from circumstantial 
evidence, i.e. by correlating population trait values from a common garden experiment with environmental conditions from the populations' origin (Linhard \& Grant, 1996; Weber \& Schmid, 1998; Scheepens et al., 2013). However, unequivocal evidence of local adaptation requires reciprocal transplantation experiments between a minimum of two and preferably more populations, and testing whether the outcome is compatible with divergent selection (Kawecki \& Ebert, 2004; Blanquart et al., 2013). The test criteria for evaluating the outcome of reciprocal transplantations, the "local vs. foreign" and the "home vs. away" contrast are not strictly equivalent, and sometimes ambiguous, because confounding effects with habitat quality and population performance may arise. The "local vs. foreign" criterion compares the fitness of the local population at its home site to the fitness of foreign populations, while the "home vs. away" criterion compares the fitness of each population when grown at its home site to the fitness when this population is grown at away sites. In pairwise comparisons, strict evidence of local adaptation is only present when the local plants outperform the foreign plants at both sites. A recent meta-analysis by Leimu \& Fischer (2008) suggests, that local adaptation is less common in plant populations than generally assumed when tests are based on the stringent criteria as mentioned above. Lack of local adaptation may result from similarity of transplant sites, high gene flow among nearby sites, high plasticity of populations, lack of genetic diversity, or founder effects during colonization (Rapson \& Wilson 1988, Anderson \& Geber 2010, Cheplick, 2015 for further references).

Here, we test the hypothesis of local adaptation in two populations of Poa alpina from two alpine grassland sites of a local flora in the Swiss Alps by reciprocally transplanting clonally produced offspring among them. The study was motivated by the observation that $P$. alpina plants from the two nearby sites differ in their reproductive mode, producing either exclusively seeds or exclusively bulbils. P. alpina is a common grass species in the upper montane and alpine zone of the European Alps (Müntzing, 1980; Conert et al.,1998). Population differentiation in this species is high, probably as a consequence of polyploidy, facultative apomixis of seeds and pseudo-vivipary in bulbilproducing plants (Rudmann-Maurer et al., 2007). With elevation, the occurrence of seed-producing plants is decreasing and that of bulbil-producing plants is increasing, indicating an advantage of reproduction by bulbils in harsh alpine conditions (Fischer et al., 2011; Steiner et al., 2012). The exclusive occurrence of seed-producing P. alpina in a species-rich calcareous grassland in a high-alpine flora while almost all plants of this 
species are bulbil-producing in all other habitats of the surrounding vegetation suggested the hypothesis of a selective advantage being responsible for this distribution. We therefore used seed-producing plants of $P$. alpina from the nutrient-rich calcareous grassland site (Festucetum), and bulbil-producing plants from a nearby low-productivity grassland on acidic soil (Nardetum) for a reciprocal transplantation experiment to test for local adaptation of established plants and for a microsatellite analysis to detect their level of genetic differentiation.

We asked the following specific questions: (1) In the molecular analysis: do the two nearby populations of Poa alpina differ in their genetic diversity, and how much are they differentiated from each other? (2) By reciprocal transplantation: can we detect local adaptation, i.e. is there a "local vs. foreign" or a "home vs. away" advantage or both of plants grown at these sites. (3) Can the distribution of seed- and bulbil-producing $P$. alpina plants be explained by local adaptation of established plants, by habitat quality, or plant performance?

\section{Material and methods}

Study species

Poa alpina L. (Poaceae) is a common arctic-alpine plant in the Northern Hemisphere (Conert, 1998). In the Alps it occurs in pastures, nutrient-rich meadows and as a pioneer species on glacier foreland, scree slopes, and snowbeds. Due to its high contents of fats and protein it is considered one of the most important fodder grasses in subalpine and alpine grassland (Bachmann, 1980; Conert, 1998). P. alpina is a polyploid complex, with highly variable, aneuploid chromosome numbers and multiple B-chromosomes (Müntzing, 1980; Steiner \& Heidenreich, 1979). In Switzerland chromosome numbers range from 22 to 61 chromosomes per plant (Duckert-Henriod \& Favarger 1987; Rudmann-Maurer et al., 2007). Plants of $P$. alpina produce either seeds, or reproduce vegetatively by forming bulbils in the panicles that grow into little plantlets on the parent plant, which are therefore called pseudo-viviparous (Müntzing 1980, Pierce 1998). The plantlets may dehisce from the parent plant and can eventually root and establish quickly (Pierce, 1998). The reproductive mode is largely genetically determined (Rudmann-Maurer et al. 2007; Steiner et al., 2007). Pseudo-vivipary is 
probably evolving locally from seminiferous populations as proposed by Wilkinson and Stace (1991) and demonstrated by Chiurugwi et al. (2011) for Festuca vivipara. According to Müntzing (1933) seeds of seminiferous plants are either produced sexually or apomictically. Steiner et al. (2012) found between 7 to $8 \%$ of the offspring from seedproducing Poa alpina to differ genetically from their mother and therefore to be produced via sexual reproduction. The frequency of seed-producing plants decreases and that of bulbil-producing plants increases with elevation suggesting an advantage of reproduction by bulbils in harsher and colder conditions (Fischer et al. 2011; Steiner et al., 2012).

\section{Study site}

The study locations are two S- and SE-exposed natural grassland sites near the Furka Pass ( $46^{\circ} 34^{\prime} \mathrm{N} 8^{\circ} 25 \mathrm{E}$ ) at almost identical elevation (2390 and $2430 \mathrm{~m}$ a.s.l.). The two sites selected for the reciprocal transplantation differ in their soil type, vegetation, and productivity. Mean annual precipitation at the study location is c. $1600-1900 \mathrm{~mm}$, with a growing-season length between 2.5 and 3.5 month, and a mean growing-season temperature (mid Jun-Aug) of c. $7.5^{\circ} \mathrm{C}$. (measured by a weather station at the study location). The more productive site is a species-rich grassland with calcium- and nutrient-rich, relatively deep soil, on a S-exposed and steep slope, dominated by Festuca violacea and a pH around 5 (Festucetum). Poa alpina plants at this site are almost exclusively seed-producing. The other site, in less than $200 \mathrm{~m}$ distance, is a species-poor low-productivity grassland with an acidic soil, on a SE-exposed flat slope, dominated by Nardus stricta and Carex curvula and a pH around 4 (Nardetum). Here, P. alpina is almost exclusively bulbil-producing. Due to differences in slope and exposition, snow melt at the calcareous grassland site is usually three to four weeks earlier and, accordingly, the growing-season length is longer and maximal development of the vegetation is reached earlier.

\section{Sampling, plant propagation and reciprocal transplantation}

In July 2012 we randomly sampled 22 Poa alpina plants in each of the two study sites described above. To reduce sampling of genetically identical individuals as much as possible, the minimum distance among samples was $2 \mathrm{~m}$. We transplanted the 44 plants into multitrays containing 28 cells of $6 \mathrm{~cm}$ diameter in low-nutrient soil, (Anzuchterde, Ökohum, Herrenhof, Swizerland), clipped them to a standard size of $2 \mathrm{~cm}$ above ground 
and brought them into a glasshouse at the Botanical Institute in Basel, Switzerland (260 $m$ a.s.l.) to reduce carry-over effects. After two months, the plants consisted of several tillers, which we isolated from each other to obtain on average four clonal offspring from each initially sampled genotype. The re-potted plants remained in the glasshouse in Basel until the end of October, when they were cut back again to a standard size of $2 \mathrm{~cm}$ above ground and brought back to the study location on the Furka Pass. The clonal offspring from each plant of both populations were randomly assigned to the two sites and transplanted in several rows and two blocks per site into the local soil of the two transplant sites, i.e. the rich calcareous grassland (Festucetum) and the nutrient-poor grassland on acidic soil (Nardetum). In total, 137 offspring from 37 genotypes were reciprocally transplanted, 67 originating from the rich calcareous grassland (Festucetum), and 70 from the nutrient-poor grassland (Nardetum), respectively. The two sites (Festucetum and Nardetum) received 68 and 69 plants, respectively, and c. half of the transplanted plants in each site came from the two populations. Mortality after the first overwintering did not depend on site or origin. We found 26 dead plants, and 4 plants did not increase in biomass or died later. The remaining 107 plants from 31 genotypes were used for measurements.

We harvested aboveground biomass at the end of the first growing season in September 2013 by cutting leaves $0.5 \mathrm{~cm}$ above soil level. Only very few plants had reproduced by that time. In 2014, we harvested aboveground biomass again in the same way at peak flowering, on 15th July in the Festucetum, and on 24th July in the Nardetum. At this time all plants were reproducing and we counted the number of inflorescences of each plant. Harvested plant material was dried for 48 hours at $90^{\circ} \mathrm{C}$ and weighed.

\section{Data analysis}

We performed linear mixed-model analyses with transplant site and origin as well as their interaction as fixed effects and genotypes nested within origin and its interaction with transplant site as random effects using the lmerTest package of R (R Development Core Team, 2009). ImerTest allows F-tests for fixed effects and likelihood-ratio tests for random effects using stepwise model reduction and comparison. Type 3 sums of squares and Satterthwaite approximations for degrees of freedoms were used for calculations. Untransformed data were used (Crawley, 2007). 
Maurer et al. (2005) developed microsatellite primers for five loci of P. alpina. Details on the five polyploid loci, PCR conditions, and horizontal Spreadex ${ }^{\circledR}$ gel electrophoresis (Elchrom Scientific, Cham, Switzerland) of the PCR amplicons are described in Maurer et al. (2005), and in Steiner et al. (2012), respectively. In brief, DNA was extracted from silica-dried leaf material of the 22 plants from the Festucetum (seed-producing individuals) and the 22 plants from the Nardetum (bulbil-producing specimens). PCR was done with the illustra ${ }^{\mathrm{TM}}$ puReTaq Ready-To-Go PCR Beads (GE Healthcare, Buckinghamshire, UK). The beads give reliable PCR products in the resolution of microsatellite banding pattern using Spreadex gels. In a pre-analysis, four unrelated individuals together showed a total of 154 bands at the five microsatellite loci. In a repetition PCR run of the same individuals, five mismatch bands were found, i.e. 5/154 = $0.03=3 \%$. This means an acceptable replication rate in the banding pattern of $97 \%$. Molecular diversity among the two study populations was analysed following the procedure for polyploid microsatellite data of $P$. alpina described by Rudmann-Maurer et al. (2007). In all 44 individuals, the presence/absence of alleles were 1/0-coded as for dominant markers, and GenAlEx ver. 6.2. (Peakall \& Smouse, 2006) was used for detecting identical multilocus genotypes and to perform an analysis of molecular variance (AMOVA). Genetic diversity was measured as the number of allelic bands per individual genotype and this measure was used to test for differences in genetic diversity among populations and among seed- and bulbil-producing populations. The $1 / 0$ data matrix was also used for the reconstruction of an unrooted, individual-based UPGMA dendrogram (see Appendix A). The UPGMA clustering based on Jaccard index was run on the online platform ,DendroUPGMA' at the University of Rovira i Virgili (URV), Tarragona, Spain (Garcia-Vallvé \& Puigbo, 2002).

\section{Results}

\section{Genetic diversity}

Among the 44 sampled plants of Poa alpina, altogether 44 distinct allelic bands were found at the five microsatellite loci, between 6 and 9 per locus. We found 40 multilocus phenotypes, 21 among the 22 plants from the Festucetum, and 19 among the 22 plants from the Nardetum. 
The genetic diversity, measured as the number of allelic bands per individual, did not differ between the seed-producing plants from the Festucetum $(13.1 \pm 0.5$, mean \pm s.e. $)$, and the bulbil-producing plants from the Nardetum $(13.5 \pm 0.5, t=0.6$, df 33.1, n.s.). In the AMOVA analysis we detected high molecular differentiation between the two populations (Table 1). 35\% of the variation came from the variation in microsatellite bands among populations, and the remaining 65\% from within-population variation. The high differentiation is reflected by a high number of private alleles observed. Nine private alleles were found in the plants from the Festucetum and eight in the plants of the Nardetum. In the UPGMA-dendrogram of the banding pattern the plants from the two populations appear in separate clusters (see Appendix A).

\section{Habitat quality and population performance}

All plants were on average significantly larger and reproduced more on the calcareous grassland site (Festucetum) compared to growth on the grassland on acidic soil (Nardetum, Fig. 1, Table 2). 28 of 31 genotypes performed better when grown on the calcareous grassland site. Across both populations, mean biomass of plants in the first year (2013) was $226 \pm 21 \mathrm{mg}$ when grown in the Festucetum vs. $107 \pm 8 \mathrm{mg}$ when grown in the Nardetum, and in the second year (2014) biomass was $754 \pm 75 \mathrm{mg} v s .261 \pm 22$ $\mathrm{mg}$, respectively. All plants reproduced at both sites.

Performance was dependent on the origin of plants, indicating differences in intrinsic population performance (Table 2). Across both sites, biomass of seed-producing plants from the rich calcareous grassland was $47 \%$ and $45 \%$ larger than the biomass in the first and second year, respectively. The mean number of inflorescences in the second growing season was $4.4 \pm 0.5$ for the plants of the Festucetum, and $2.0 \pm 0.2$ for those from the Nardetum.

\section{Local adaptation}

In the first year (2013) the site x origin interaction for biomass was significant (Table 2). This was due to the large advantage of seed-producing plants at their home site compared to the bulbil-producing foreign plants (71\% higher biomass). However, in 2014 the interaction was not significant anymore (Table 2), and the aforementioned advantage of the seed-producing plants at their home site was smaller (36\%). Qualitatively similar results were obtained for fitness expressed as numbers of 
inflorescences: P. alpina from the Festucetum had $5.8 \pm 0.5$ inflorescences at its home and $2.9 \pm 0.6$ at the away site compared to $1.1 \pm 0.5$ of $P$. alpina from the Nardetum at the home site and $2.9 \pm 0.5$ at the away site (Fig. 1 C).

The seed-producing plants from the Festucetum performed always better at their home site compared to the performance at the away site. Also, plants of this population performed better at their local site compared to the foreign population. However, the opposite was the case for the bulbil-producing plants from the Nardetum, which performed always better at the away site and were mostly outperformed at their local site by the foreign plants (Fig. $1 \mathrm{~A}, \mathrm{~B}, \mathrm{C}$ ). Only in the first year was the performance in the Nardetum similar for both populations (2013, Fig. 1 A), while in the second year the foreign population performed better than the local population in the Nardetum (2014, Fig. 1 B, C). Thus, the "home vs. away" and the "local vs. foreign" criterion was satisfied only for the population from the Festucetum, but not for the population from the Nardetum.

Overall, genotypes did not differ in their growth and reproduction but in the second year they developed differently when their growth was compared among the two study sites (Table 2). Results at the genotype level were very consistent and similar to those at the population level. 13 of the 16 genotypes originating from the Festucetum, and all 15 genotypes from the Nardetum performed better when grown on the calcareous site. Also, most genotypes of the Festucetum outperformed the best Nardetum genotypes at the Nardetum site, indicating that established genotypes were not locally adapted.

\section{Discussion}

By reciprocal transplantation of a seed- and a bulbil-producing population of Poa alpina from nearby grassland sites we could not detect local adaptation of established plants. Nevertheless, plants from the two populations differed genetically in performance, with the seed-producing plants from the Festucetum yielding higher biomass and having more inflorescences compared to the bulbil-producing plants at both transplantation sites in 2014. Difference in habitat quality caused plants from the two populations and almost all genotypes from both origins to perform better in the calcareous soil of the 
Festucetum. These results indicate that habitat quality in combination with intrinsic plant performance and factors not investigated here explain the different distribution of seed- and bulbil producing P. alpina at the Furka Pass, but not local adaptation. Despite taking measures during propagation of plants to reduce carry-over effects, we cannot completely exclude that such effects have affected our results. However, such effects, if present, are expected to diminish over time, as has been found in other studies (Ouborg et al. 1991, Schmid \& Dolt 1994), and in a study of ourselves using clonal offspring of Poa alpina (Fischer et al. 2011). Therefore, we suggest that it is unlikely that carry-over effects were of great importance with respect to our results.

\section{Molecular diversity and performance of seed-and bulbil-producing Poa alpina}

The microsatellite analysis revealed that seed- and bulbil-producing populations of Poa alpina were equally diverse but strongly differentiated from each other in their allelic composition and by a high number of private alleles. The two populations are thus largely independent units with no or only little genetic relationship. On the one hand, seed-producing P. alpina plants are facultative apomicts (Müntzing, 1933), and the percentage of sexually produced seeds is relatively high with c. $8 \%$ compared to what is known from other apomictic species (Asker \& Jerling 1992, Steiner et al., 2012). The residual sexuality in P. alpina in seed-producing genotypes seems high enough to purge deleterious mutations and to allow for natural selection (Asker \& Jerling, 1992; van der Hulst et al., 2003). Evidence for adaptation in P. alpina to human land use (Fischer et al., 2011) is a clear indication of ongoing natural selection in this species. On the other hand, bulbil-producing genotypes are an evolutionary dead-end because they reproduce exclusively asexually by bulbils and never produce seeds (Darlington, 1958). The high number of multilocus genotypes in the bulbil-producing population suggests that the formation of bulbil-producing cytotypes from seminiferous plants happens relatively frequently. Occasional gene flow from bulbil-producing cytotypes to seed-producing facultative apomicts is not completely excluded, since pseudo-viviparous plants may occasionally develop a sexual (male) floret at the base of vegetative bulbils (Müntzing, 1980, Pierce et al., 2003). However, this is rarely the case in the field, if at all (RudmannMaurer, 2007; Fischer et al., 2011, and personal observation). Their strong genetic differentiation may explain why the two populations differ so much in their performance. It is conceivable that the residual sexuality in seed-producing cytotypes allows for the selection of high-performing genotypes, while this is not the case in the 
bulbil-producing plants, which produce exclusively clones. Similar to our results, Steiner et al. (2012) found in several common gardens at different elevation that bulbilproducing P. alpina plants were always less vigorous than seed-producing ones. Thus, lower performance of bulbil-producing cytotypes in P. alpina seems to be a general phenomenon and may be a consequence of their asexuality and genetic separation from seminiferous plants. The increase of bulbil-producing plants with elevation can thus hardly be explained by the performance of established plants and may therefore depend on other advantages, possibly through better establishment rates of bulbil-derived offspring under the relatively cold and wet conditions at high elevation and due to a short growing season, as has been discussed for pseudo-viviparous grasses in general (Lee \& Harmer, 1980) and also suggested from results of Fischer et al. (2011) and Steiner et al. (2012).

\section{Reciprocal transplantation pattern}

The outcome of the reciprocal transplantation of seed- and bulbil-producing P. alpina between nearby grassland sites was clearly not in line with the hypothesis of local adaptation of established plants. In the pairwise comparisons of several performance traits neither the "local vs. foreign" nor the "home vs. away" criteria were fulfilled. As a consequence, not divergent natural selection but other processes and the intrinsic differences between the origin of the two populations must be the cause of their different distribution.

Obviously, the calcareous grassland is qualitatively a much better habitat for both $P$. alpina populations. At a closer look, this is not surprising: the soil in the Festucetum is deeper, more nutrient-rich, snow-melt is three to four weeks earlier, solar insolation and soil temperature are higher due to exposition and slope, and the overall duration of the growing season is c. one month longer (Christoph Mullis, unpublished data). Vice versa, in the nutrient-poor grassland on acidic soil both populations performed poorly, which can be explained by the combined effect of low nutrients, late snow-melt and the shorter growing season.

The almost exclusive occurrence of high-performing seed-producing genotypes in the Festucetum might result from several non-exclusive reasons. Firstly, despite the missing evidence for local adaptation between the two sites, hidden adaptation of seedproducing genotypes to their home-site might have occurred. The residual sexuality in facultative apomicts allows continuously for the formation of new genotypes that can 
then be subject to natural selection. The higher vigour of the plants from the Festucetum could thus result from directional selection of high-performing genotypes in the calcareous grassland site itself. Such directional selection cannot be revealed by reciprocal transplantation and remains a speculation. Secondly, the seed-producing genotypes could be high-performing generalists which were selected in the past at other locations due to their high fitness and which were dispersed and established easily at the high-quality site. From our study we cannot distinguish between the above two possibilities. Whatsoever, they do not explain, why pseudo-viviparous plants are missing in the Festucetum. Bulbil-producing plants are likely to be bad competitors in the species-rich, productive calcareous grassland because of their low vigour. In addition, the bulbils, which remain well attached to their reproductive stems for a long time, are not far dispersed, which may make them a rare occurrence outside of their local habitat. Winkler et al. (2010) observed that during primary succession seeds are more successful than bulbils with increasing vegetation density. Hence, dispersal limitation of bulbils together with their low performance are the likely causes for the absence of bulbil-producing P. alpina in the Festucetum.

More difficult to explain is why seed-producing plants are missing in the Nardetum, despite their much better performance compared to the bulbil-producing local genotypes. A first reason could be the rarity of seed-producing plants in the local flora of the Furka Pass (Hefel \& Stöcklin, 2010). Grassland on calcareous soil where seedproducing P. alpina plants occur is limited to a small area in this region. Silicious bedrock with grassland dominated by Nardus stricta and Carex curvula or scree vegetation where P. alpina is almost exclusively bulbil-producing prevail in the flora of the Furka Pass. Therefore, despite grass seeds being dispersed relatively far by wind (Cheplick, 1998), the seed rain from seed-producing P. alpina may be relatively low in the Nardetum.

Furthermore, if seeds arrive and successfully germinate they have still a disadvantage compared to bulbils. After germination and establishment it takes seeds usually three years to become reproducing (Matthews, 1992). Bulbils consist of already three to four leaves when released from the maternal plant, they have a higher nutrient capital, are non-dormant and able to establish immediately. Plants grown from bulbils can reproduce already in the second year (Lee \& Harmer, 1980). The aforementioned advantages of bulbils are probably the main reason for the high occurrence of bulbil- 
producing plants in cold, wet and short growing-season conditions at higher elevation. If a seed-producing P. alpina would get established in the Nardetum, late snow-melt and the short growing season might still limit successful establishment compared to the already more frequent bulbils.

\section{The local occurrence of seed- and bulbil-producing Poa alpina}

Understanding species distribution patterns is among the most challenging questions in plant ecology. Historical processes such as migration, speciation, or cytotype formation in a polyploid complex as Poa alpina determine the pool of species, subspecies or ecotypes in a particular region (Zobel, 1992). The local occurrence is then determined by environmental filtering, the availability of suitable habitats and the potential of plants to colonize them (Keddy, 1992; Maire et al., 2012). The colonizing capacity of species is determined by their fundamental and realized niche (Hutchinson, 1957). Metapopulation theory and available evidence suggests that at a given moment only a fraction of suitable habitats will be occupied, because of dispersal and microsite limitations (Hanski \& Gilpin, 1997, Munzbergova \& Herben, 2005). Thus, divergent selection of populations in different habitat conditions is only one among many processes explaining the current distribution of species. It is therefore not surprising that local adaptation is less frequent as commonly assumed (Leimu \& Fischer, 2008). Local adaptation has been detected at very small spatial scales, for instance among closely located subpopulations of trees (Sork et al. 1993), along altitudinal gradients (Galen et al. 1991, Byars et al. 2007), or along a snow-melt gradient (Kawai \& Kudo 2011). However, because adaptive processes are inherently slow, constrained by gene flow and scale-dependent, local adaptation is more likely to be found the continental or regional scale than at the small spatial scale (Joshi et al., 2001; Becker et al., 2006). This may apply even more to a species composed of a mixture of cytotypes which in $P$. alpina are formed at an unknown rate. The strong molecular differentiation of the seedand bulbil-producing populations at the Furka Pass resulted in a distinguished clustering of the studied genotypes (see Appendix A) indicating clearly separated gene pools and a different evolutionary history which is probably less related to selection than to unknown factors of cytotype formation in the past. However, the process of cytotype formation still remains a mystery (Matzk \& al., 2005). 
As we were not able to detect local adaptation of established plants by our reciprocal transplantation, the most parsimonious explanation for the striking separation of seedand bulbil-producing P. alpina on the Furka Pass is environmental filtering by the distinct habitats of the two study sites as revealed by our experiment. The supposed filtering process is certainly related to the difference in the intrinsic quality of seed-and bulbil producing plants, which is accentuated in their respective habitats on the Furka, and probably related to the different regeneration niche, i.e. the different dispersal and establishment properties of their propagules, that is to say their seeds and bulbils.

\section{Acknowledgements}

We thank E. Hiltbrunner and the Alpfor-Team at the Furka Pass for assistance during experimentation, several students from the University of Basel for help during harvesting and measurements and S. Riedl for preparing the Figure. H. Kesselring and JF Scheepens made helpful comments on earlier versions of the manuscript. The research presented here was supported financially through the Swiss National Science Foundation (project no. 31003A_135611/1) to Jürg Stöcklin.

\section{Appendix A. Supplementary data}

Supplementary data associated with this article can be found, in the online version, at XXXXX.

\section{References}

Aeschimann, D., Lauber, K., Moser, D.M., Theurillat, J.-P. (2004). Flora alpina (3 volumes). Haupt, Bern.

Anderson, J.T. \& Geber, M.A. (2010). Dempgraphic source-sink dynamics restrict local adaptation in Elliot's blueburry (Vaccinium elliottii). Evolution 64: 370-384.

Antonovics, J. (1976). The nature of limits to natural selection. Annals of the Missouri Botanical Garden, 63: 224-247.

Asker, S.E., Jerling, L. (1992). Apomixis in plants. CRC Press, Boca Raton, Florida, USA. 
Bachmann, M.A. (1980). Oekologie und Breeding System bei Poa alpina L. PhD thesis, University of Zürich.

Becker, U., Colling, G., Dostal, P., Jakobsson, A., Matthies, D. (2006). Local adaptation in the monocarpic perennial Carlina vulgaris at different spatial scales across Europe. Oecologia, 150: 506-518.

Bennington, C.C., McGraw, J.B. (1995). Natural selection and ecotypic differentiation in Impatiens pallida. Ecological Monographs, 65: 303-323.

Blanquart, F., Kaltz, O., Nuismer, S., Gandon, S. (2013). A practical guide to measure local adaptation. Ecology Letters, 16: 1195-1205.

Bowmann, G., Perret, C., Hoehn, S., Galeuchet, D.J., Fischer, M. (2008). Habitat fragmentation an adaptation: a reciprocal transplant experiment among 15 populations of Lychnis flos-cuculi. Journal of Ecology, 96:1056-1064.

Byars, S.G., Papst, W., Hoffmann, A.A. (2007). Local adaptation and cogradient selection in the alpine plant Poa hiemata, along a narrow altitudinal gradient. Evolution. 61: 2925-2941.

Byars, S.G., Hoffmann, A.A. (2009). Lack of strong local adaptation in the alpine forb Craspedia lamicola in southeastern Australia. International Journal of Plant Sciences, 170: 906-917.

Chapin, F.S., Körner, Ch. (eds). (1995). Arctic and alpine biodiversity: patterns, causes and ecosystem consequences. Ecological Studies, 113, Springer, Berlin.

Cheplick, G.P. (1998). Population Biology of Grasses. Cambridge, Ney York.

Cheplick, G.P. (2015). Approaches to Plant Evolutionary Ecology. Oxford Univ. Press

Chiurugwi, T., Beaumont, M.A., Wilkinson, M.J., Battey, N.H. (2011). Adaptive divergence and speciation among sexual and pseudoviviparous populations of Festuca. Heredity, 106: 854-981.

Chun, Y.J., Nason, J.D., Moloney, K.A. (2009). Comparison of quantitative and molecular genetic variation of native vs. invasive populations of purple loosestrife (Lythrum slicaria L., Lythraceae). Molecular Ecology 18: 3020-3035.

Clausen, J., Keck, D.D., Hiesey, W.M. (1948). Experimental studies on the nature of species. III. Environmental respones of climatic races of Achillea. Publications of the Carnegie Institution of Washington, 581: 114-133.

Comes, H.P., Kadereit, J.W. (1998). The effect of Quaternary climatic changes on plant distibution and evolution. Trends in Plant Sciences, 3: 432-438. 
Comes, H.P., Kadereit, J.W. (2003). Spatial and temporal patterns in the evolution of the flora of the European Alpine System. Taxon, 52: 451-462.

Conert, H.J. (1998). 14. Poa alpina. In H. J. Conert, E. J. Jäger, J. W. Kadereit, W. SchultzeMotel, and H. E. Weber [eds.], Gustav Hegi. Illustrierte Flora von Mitteleuropa, 690693. Parey Buchverlag, Berlin, Germany.

Crawley, M.J. (2007). The R book. John Wiley, Chichester, UK.

Darlington, C.D. (1958). Apomixis: The Escape. In: Evolution of Genetic Systems. Oxford, Olivier and Boyd LTD.: pp. 157-168.

Darwin, C. (1859). On the origin of species by means of natural selection, or the preservation of favoured races in the struggle for life. $1^{\text {st }}$ ed., London: J. Murray, London.

Schmid, B., Dolt, C. (1994). Effects of maternal and paternal environment and genotype on offspring in Solidago altissima L. Evolution 48: 1525-1549.

Duckert-Henriod, M.M., Favarger, C. (1987). Contribution à la cytotaxonomie e à la cytogéographie des Poa de la Suisse. Birkhäuser Verlag, Basel, Switzerland.

Ebeling, S.A., Stöcklin, J., Hensen, I., Auge, H. (2011). Multiple common garden experiments suggest lack of local adaptation in an invasive ornamental plant. Journal of Plant Ecology 4: 209-220.

Fischer, M., Weyand, A., Rudmann-Maurer, K., Stöcklin, J. (2011). Adaptation of Poa alpina to altitude and land use in the Swiss Alps. Alpine Botany, 121: 91-105.

Frei, E.S., Scheepens, J.F., Armbruster, G.F.J., Stöcklin, J. (2012). Phenotypic differentiation in a common garden reflects the phylogeography of a widespread Alpine plant. Journal of Ecology, 100: 297-308.

Galen, C., Shore, J.S., Deyohe, H. (1991). The ecotypic divergence in alpine Polemoniumviscosum - genetic structure, quantitative variation, and local adaptation. Evolution, 45: 1218-1228.

Garcia-Vallvé, S., Puigbo, P. (2002). DendroUPGMA: A dendrogram construction utility. Available at http://genomes.urv.cat/UPGMA/.

Hanski, L., Gilpin, L. (1997). Metapopulation Biology: Ecology, Genetics, and Evolution. Academic Press, London.

Hautier, Y., Randin, C.F., Stöcklin, J., Guisan, A. (2009). Changes in reproductive investment with altitude in an alpine plant. Journal of Plant Ecology, 2: 125-134. 
Harder, L.D., Johnson, S.D.. (2009). Darwin's beautiful contrivanes: evolutionary and functional evidence of floral adaptation. New Phytologist, 183: 530-545.

Hefel, C., Stöcklin, J. (2010). Flora der Furka. Bauhinia, 22: 33-59.

Hutchinson, G.E. (1957). Concluding remarks. Cold spring Harbor Symposia on Quantitative Biology, 22: 415-427.

Joshi, J., Schmid, B., Caldeira, M.C., Dimitrakopoulos, P.G., Good, J., Harris, R., Hector, A., Huss-Danell, K., Jumpponen, A., Minns, A., Mulder, C.P.H., Pereira, J.S., Prinz, A, SchererLorenzen, M., Siamantziouras, A.-S.D., Terry, A.C., Troumbis, A.Y., Lawton, J.H. (2001). Local adaptation enhances performance of common plant species. Ecology Letters, 4: 536-544.

Kawai, Y., Kudo, G. (2011) Local differentiation of flowering phenology in an alpine snow-bed herb Gentiana nipponica. Botany 89: 361-367.

Kawecki, T.J., Ebert, D. (2004). Conceptual issues in local adaptation. Ecology Letters, 7:1225-1241.

Keddy, A. (1992). Assembly and response rules: two goals for predictive community ecology. Journal of Vegetation Science, 3: 157-164.

Körner, Ch. (2003). Alpine plant life: Functional Plant Ecology of High Mountain Ecosystems. Springer, Berlin, second edition.

Lee, J.A., Harmer, R.. 1980. Vivipary, a reproductive strategy in response to environmental stress. Oikos, 35: 254-265.

Leimu, R., Fischer, M. (2008). A Meta-Analysis of local adaptation in plants. Plos ONE, 3: Artn e 4010.

Linhart, Y.B., Grant, M.C. (1996). Evolutionary significance of local genetic differentiation in plants. Annual Review of Ecology and Systematics, 27: 237-277.

Maire, V., Gross, N., Börger, L., Roulx, R., Wirth, C., da Silveira Pontes, L., Soussana, J.-F., Louault, F. (2012). Habitat filtering and niche differentiation jointly explain species relative abundance within grassland communities along fertility and disturbance gradients. New Phytologist, 196: 497-509.

Manel, S., Gugerli, F., Thuiller, W., Alvarez, N., Legendre, P., Holderegger, R., Gielly, L., Taberlet, P. (2012). Broad-scale adaptive genetic variation in alpine plants is driven by temperature and precipitation. Molecular Ecology, 21: 3729-3738. 
Matthews, J.A. (1992). The Ecology of Recently-declaciated Terrain. A Geoecological Approach to Glacier Forelands and Primary Succession. Cambridge Studies in Ecology. Cambridge/New York, Cambridge University Press.

Matzk, F., Prodanovic, S., Bäumlein, H., Schubert, I. (2005). The inheritance of apomixis in Poa pratensis confirms a five locus model with differences in gene expressivity and penetrance. The Plant Cell, 17:13-24.

Maurer, K., Gautschi, B., Weyand, A., Stöcklin, J., Fischer, M. (2005). Isolation and charcterization of microsatellite DNA markers in the grass Poa alpina L. Molecular Ecology Notes, 5: 719-720

McGraw, J.B. (1987). Experimental ecology of Dryas octopetala ecotypes. IV. Fitness response to reciprocal transplanting in ecotypes with different plasticity. Oecologia, 73: 465-468.

Munzbergova, Z. (2004). Effect of spatial scale on factors limiting species distribution in dry grassland fragments. Journal of Ecology, 92: 854-867.

Munzbergova, Z., Herben, T. (2005). Seed, dispersal, microsite, habitat and recruitment limitation: identification of terms and concepts in studies of limitations. Oecologia, 145: 1-8.

Müntzing, A. (1933). Apomictic and sexual seed formation in Poa. Hereditas. 17: 131-154.

Müntzing,, A. (1980). Mode of propagation and chromosomal peculiarities in Scotch material of Poa alpina. Hereditas, 92:291-296.

Ouborg, N.J., van Treuren, R., van Damme, J.M.M. (1991). The significance of genetic erosion in the process of extinction. II. morphological variation and fitness components in populations of varying size of Salvia pratensis and Scabiosa columbaria. Oecologia 86: 359-367.

Peakall, R., Smouse, P.E. (2006) GENALEX 6: Genetic Analysis in Excel. Population genetic software for teaching and research. Molecular Ecology Notes, 6: 288-295.

Pierce, S. (1998). Resource allocation in the pseudoviviparous Alpine Meadow Grass (Poa alpina L.). PhD Thesis, University of Durham, UK.

R Development Core Team. (2009). R: A language and environment for statistical computing. R Foundation for Statistical Computing, Vienna, Austria. ISBN 3-90005107-0, website http://www.R-project.org.

Rapson, G.L. \& Wilson, J. B. 1988. Non-adaptation in Agrostis capillaris L. (Poaceae). Functional Ecology 2: 479-490. 
Rudmann-Maurer, K., Weyand, A., Fischer, M., Stöcklin, J. (2007). Microsatellite diversity of the agricultarly important Poa alpina L. in the Swiss Alps. Annals of Botany, 100: 1249-1258.

Scheepens, J.F., Stöcklin, J. (2011). Glacial history and local adaptation explain differentiation in phenotypic traits in the Alpine grassland herb Campanula barbata. Plant Ecology and Diversity, 4: 403-413

Scheepens, J.F., Frei, E.S., Stöcklin, J. (2013). Glacial history affected phenotypic differentiation in the Alpine Plant Campanula thyrsoides. PLoS ONE, 8(10): e73854.

Scherrer, D., Körne,r C. (2010). Infra-red thermometry of alpine landscapes challenges climatic warming projections. Global Change Biology, 16: 2602-2013.

Sedlacek, J., Wheeler, J.A., Cortés, A.J. Bossdorf, O., Hoch, G., Lexer, C., Wipf, S., Karrenberg, S., van Kleunen, M., Rixen, C. (2015). The response of the alpine dwarf shrub Salic herbacea to altered snowmelt timing: lessons from a multi-site transplant experiment. PLos One: e0122395

Steiner, A.M., Heidenreich, S.C. (1997). Verification of varieties of alpine meadow-grass (Poa alpine L): floret morphology, chromosome number and single seed storage porotein electrophoresis. Plant Varieties and Seeds, 10: 129-134.

Slatkin, M. (1987) Gene flow and the geographic structure of natural populations. Science 236: 787-792.

Steiner, B.L., Armbruster, G.F.J., Scheepens, J.F., Stöcklin, J. (2012). Distribution of bulbiland seed producing plants of Poa alpina (Poaceae) and their growth and reproduction in common garden suggest adaptation to different elevations. American Journal of Botany, 99:2035-2044.

Stöcklin, J., Kuss, P., Pluess, A.R. (2009). Genetic diversity, phenotypic variation and local adaptation in the alpine landscape: case studies with alpine plant species. Botanica Helvertica, 119: 125-133.

Turesson, G. (1922). The plant species in relation to habitat and climate. Hereditas, 6: 147-236.

van der Hulst, R.G.M., Mes, T.H.M., Falque, M., Stam, P., Nijs Den, J.C.M., Bachmann, K. (2003). Genetic structure of a population sample of apomictic dandelions. Heredity, 90: 326-335. 
Weber, E., Schmid, B. (1998). Latitudinal population differentiation in two species of Solidago (Asteraceae) introduced into Europe. American Journal of Botany, 85: 110121.

Weiss-Schneeweiss, H., Emadzade, K., Jang T.S., Schneeweiss, G.M. (2013) Evolutionary consequences, constraints and potential of polyploidy in plants. Cytogenetic and genome research 140: 137-150.

Wilkinson, M.J., Stace, C.A. (1991). A new taxonomic treatment of the Festuca ovina L. aggregate (Poaceae) in the British Isles. Botanical Journal of the Linnean Society, 106: 347-397.

Williams, G.C. (1966). Adaptation and Natural Selection. Princeton University Press, Princeton.

Winkler, E., Marcante, S., Erschbamer, B. (2010). Demographic consequences of the two reproductive mode in Poa alpine L. along a primary succession gradient in the Central Alps. Arctic Antarctic and Alpine Research, 42: 227-235.

Young, A., Boyle, T., Brown, T. (1996) The population genetic consequences of habitat fragmentation for plants. Trends in Ecology and Evolution 11: 413-418.

Zobel, M. (1992). Plant species coexistenc-the role of historical, evolutionary and ecological factors. Oikos, 65: 314-320. 
Fig. 1. Reciprocal transplantation of seed- and bulbil-producing populations of $P o a$ alpina between a species-rich grassland on calcareous soil (Festucetum) and a nearby low-productuvity grassland (Nardetum) on the Furka Pass in the Central Swiss Alps. (A) Biomass (mean \pm se) in 2013, the first year after transplantation; (B) Biomass (mean \pm se) in 2014, including reproductive stems; (C) Number of reproductive stems (mean \pm se) in 2014 (dark shaded bars: plants originating from the Festucetum; light shaded bars: plants originating from the Nardetum).
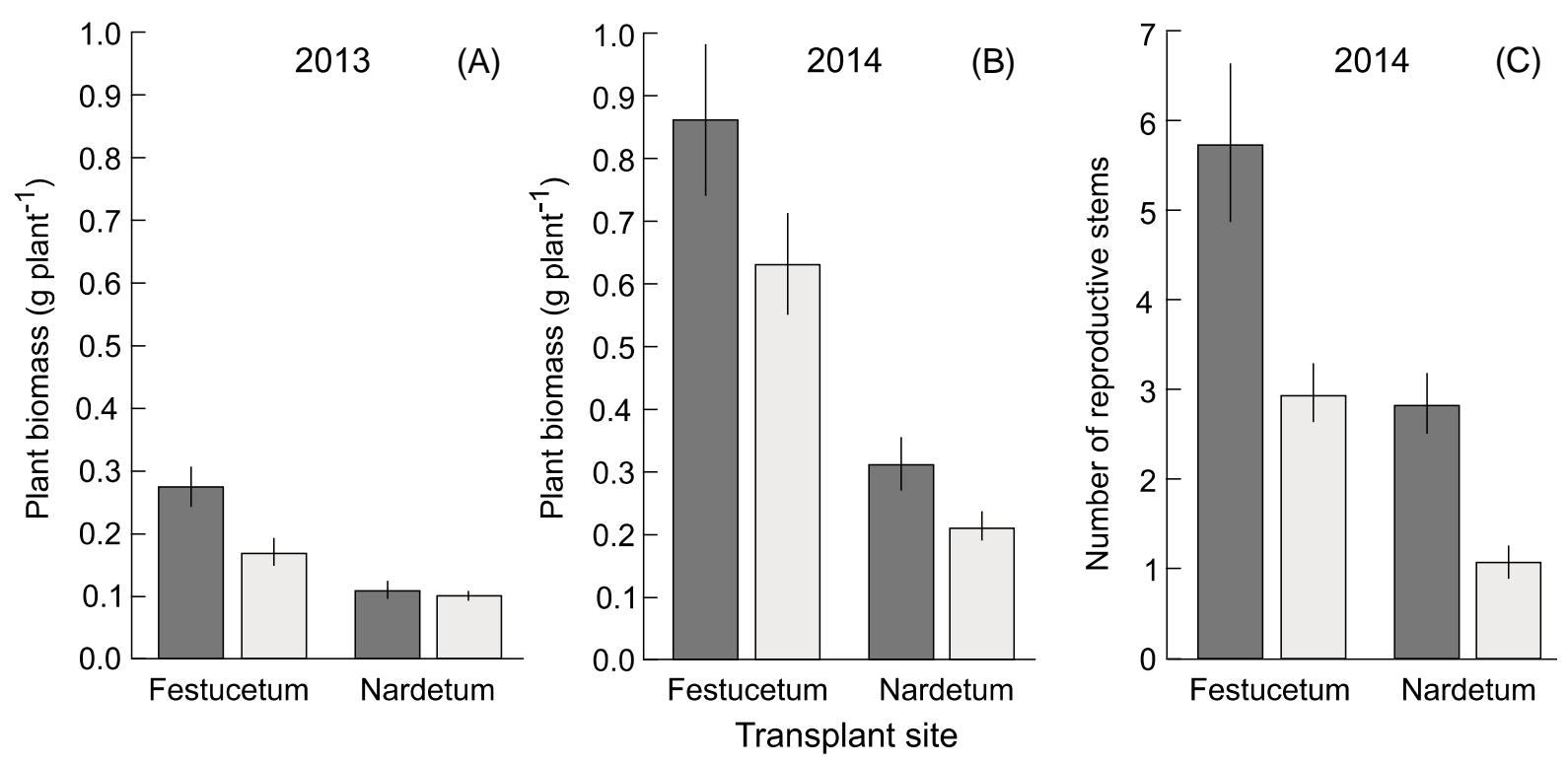
Table 1. Analysis of molecular variance (AMOVA) of two populations of Poa alpina from a calcareous grassland site (Festucetum, 21 genets) and a nearby site on acidic soil (Nardetum, 19 genets) from the Furka Pass in the Swiss Alps

\begin{tabular}{lcccccc} 
Source of variation & df & $\begin{array}{l}\text { Mean } \\
\text { squares }\end{array}$ & $\begin{array}{l}\text { Estimated } \\
\text { variance }\end{array}$ & $\begin{array}{l}\text { Variation } \\
(\%)\end{array}$ & Fixation index \\
\hline Between populations & 1 & 64.72 & 2.96 & 35 & $\Phi=0.347^{* *}$ \\
Within populations & 38 & 5.59 & 5.59 & 65 & \\
Total & 39 & 7.11 & 8.55 & &
\end{tabular}

Df, degrees of freedom. Significance of $\Phi$ is based on $1^{\prime} 000$ permutations: ${ }^{* *} P<0.01$. Significance for within population variation cannot be calculated since we used a data matrix of dominant markers, and therefore the within population variance corresponds to the error-term. 
Table 2. Results of linear mixed-effect models testing for the effects of reciprocal transplantation of Poa alpina between two grassland sites on growth (total aboveground biomass in 2013 and 2014) and no. of inflorescences (2014) at the Furka Pass in the Central Swiss Alps.

\begin{tabular}{|c|c|c|c|}
\hline Source of variation & Biomass 2013 & Biomass 2014 & $\begin{array}{l}\text { No of } \\
\text { inflorescences }\end{array}$ \\
\hline Transplant site & $30.20 * * *$ & $29.17^{* * *}$ & $20.57^{* * *}$ \\
\hline Population Origin & $7.17^{* *}$ & $4.30 *$ & $18.25^{* * *}$ \\
\hline Transplant site $\mathrm{x}$ Population origin & $5.17^{*}$ & 0.92 & 1.09 \\
\hline Genotype (random) & 0.19 & n.a. & 0.00 \\
\hline Genotype x Transplant site (random) & 1.65 & $11.00^{* * *}$ & 1.53 \\
\hline
\end{tabular}

Shown are F- and $\mathrm{X}^{2}$-values and their significance is indicated with asterisks. Genotype is nested in Population origin. Genotype and Genotype $\mathrm{x}$ Transplant site are random effects ( $\mathrm{X}^{2}$-values); other factors are fixed effects (F-values). ${ }^{*} P<0.05$; $^{* *} P<0.01$; $^{* *} P<0.001$ 


\section{Appendix A}

Individual based UPGMA dendrogram using presence/absence of alleles from five microsatellite loci in 44 genotypes of Poa alpina from a species-rich grassland on calcareous soil (Festucetum) and a nearby low-productuvity grassland on acidic soil (Nardetum) on the Furka Pass in the Central Swiss Alps.

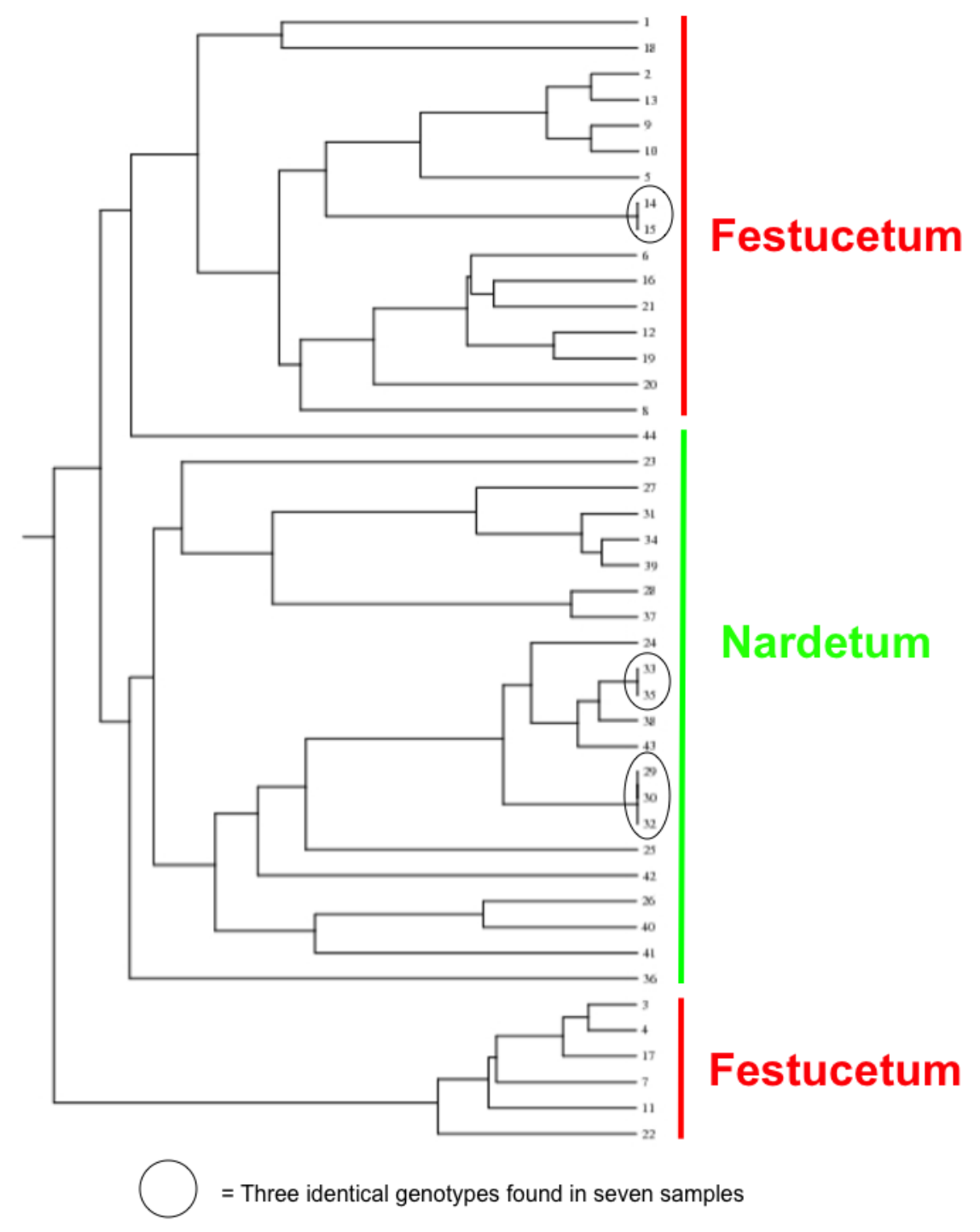

